\title{
プラズマによる立方晶窒化タンタルの生成
}

松本修・古滝敏郎

(青山学院大学 理工学部 化学科)

\section{Formation of Cubic Tantalum Nitride with Plasma Jet}

\author{
Osamu MATSUMOTO and Toshiro KOTAKI \\ $\left(\begin{array}{l}\text { Department of Chemistry, Aoyama Gakuin University } \\ \text { 16-1, Chitosedai 6-chome, Setagaya-ku, Tokyo } 157\end{array}\right)$
}

Since $\delta$-TaN, which has a cubic crystal structure, is a high temperature phase which transforms into $\varepsilon-T a N$ and $\beta$-Ta $N$, both hexagonal, below $1700^{\circ} \mathrm{C}$, it has been prepared by heating the hexagonal $\varepsilon$-TaN phase above $1700^{\circ} \mathrm{C}$ in high-pressure nitrogen. In this note, the formation of cubic $\delta$-TaN by nitriding tantalum with argon-nitrogen plasma jet under reduced pressure is described. The tantalum sheet was held on the water cooled holder in the nitriding reactor. After the evacuation of the reactor, an argon-nitrogen (10\%) gas mixture was introduced into the reactor and the pressure in the reactor was maintained at 240 Torr. The plasma jet impinged on the tantalum sheet resulting in nitridation. When the plasma jet impinged on the tantalum surface, tantalum was heated. The surface temperature was about $1850^{\circ} \mathrm{C}$. When tantalum was nitrided for $10 \mathrm{~min}, \beta-\mathrm{Ta}_{2} \mathrm{~N}$ and $\delta$-TaN were identified as products by X-ray diffraction. The lattice parameter of the cubic phase was 4. 33-4. $34 \AA$ and the composition was estimated to be $T_{a N_{0.85}}-T_{a N_{0.95}}$. The superconducting transition temperature of the specimen was about $9 \mathrm{~K}$ and it was higher than that of the mixture of $\beta-T a_{2} N, \varepsilon-T a N$ and $\delta$-TaN obtained by the heating and quenching of $\varepsilon-T a N$ by the plasma jet. The quenching rate of the tantalum sheet after the impingement of the plasma jet was calculated using a quenching model of the plate, and it was estimated to be the order of magnitude of $10^{3} \mathrm{Ks}^{-1}$. It is two orders of magnitude lower than that in the quenching of the particle of $\varepsilon$-TaN in the plasma jet.

[Received July 15, 1986]

Key-words : Cubic $\delta$-TaN, Plasma jet, High temperature phase, Nitriding, Superconductor, Quenching

\section{1. 序論}

B 1 型構造をもつ立方晶窒化タンタルの生成は Kieffer らによってはじめて武みられた ${ }^{1)}$. 彼らは高温, 高 圧下における $\mathrm{Ta}-\mathrm{N}$ 系の研究を進め, $\mathrm{Ta}-\mathrm{N}$ 系の状態図 を作成した。この状態図によれば，高圧下において六方 晶 $\varepsilon-\mathrm{TaN}$ を $1700^{\circ} \mathrm{C}$ 以上に加熱すれば B 1 型構造の $\mathrm{TaN}$ が生成されることが示されている. Boiko ら²) 30 100 kbar の圧力下, $1800^{\circ} \mathrm{C}$ 以上で六方晶 $\mathrm{TaN}$ を加 熱することによって超伝導転移温度 $6.5 \mathrm{~K}$ の B 1 構造 $\mathrm{TaN}$ を生成している.

上記のような高温, 高圧相である立方晶 $\delta$ - TaN を生 成するために著者らは六方晶 $\varepsilon-T a N$ をアルゴン-窒素混 合プラズマジェット中に供給し，加熱および急冷するこ とによって超伝導転移温度 $8.3 \mathrm{~K}$ のB 1 型 $\delta$-TaN を得 だ). 著者らはさらに 200 Torr の減圧下においてアルゴ ン-窒素混合プラズマジェットによってチタン ${ }^{4)}$ の窒化 を行い，金属表面に TiN を生成した。

本ノートにおいては, 減压下において窒素プラズマ ジェットによるタンタルの窒化を試み, 生成物について 先の六方晶 $\varepsilon-\mathrm{TaN}$ の加熱, 急冷によって得られた B 1 構造 $\mathrm{TaN}$ と比較するとともに, タンタルの窒素プラズ マジェットによる窒化の際のタンタルの加熱, 急冷につ いて検討した結果について報告する.

\section{2. 実 験}

厚さ $1 \mathrm{~mm}$ のタンタル板を $20 \times 10 \mathrm{~mm}$ に切り出し, エメリ一紙およびアルミナで研磨し, アセトンで脱脂し て窒化の試料とした.アルゴンおよび窒素は高純度品を そのまま用いた。

タンタル板の窒化に用いた装置はさきにチタンを窒化 した際に用いたものと同様であり, 反応容器内に水冷試 料台がとりつけられ, 容器の一端にとりつけられたプラ ズマトーチにより, 生成されたプラズマジェットが武料 表面を衝撃するようになっている. 窒化するタンタル板 を反応容器内の水冷試料台にとりつけ, 容器内を $10^{-1}$ Torr 以下まで排気した後に, アルゴン-窒素混合気体を プラズマトーチを通して反応容器内に導入し, 容器内圧 力を所定の圧力とした. 所定の電力をプラズマトーチに 与えてプラズマジェットを発生し，30 秒から 10 分間窒 化を行った.この際の最適窒化条件は, 容器内圧力： 240 Torr, 電力 : $2.8 \mathrm{~kW}(140 \mathrm{~A}, 20 \mathrm{~V})$, 気体流量 : $11.8 l \cdot \mathrm{min}^{-1}$, プラズマジェット中の窒素濃度：10\%で ある。

所定時間の窒化後に，生成物はX線回折によって同定 し, 四端子法による電気抵抗の測定から, 超伝導転移温 度を求めた。 


\section{3. 結果と考察}

プラズマジェットがタンタル表面を衝撃した際に，プ ラズマジェット衝撃の停止直後のタンタル表面温度を光 高温計によって測定した結果, タンタル表面温度は, $1850^{\circ} \mathrm{C}$ であった。この温度は, 立方晶 $\delta$ - TaN が安定に 存在する温度である.

窒化後の生成物の $X$ 線回折の結果, 30 秒の窒化によっ てはタンタル表面に $\beta-\mathrm{Ta}_{2} \mathrm{~N}$ の生成が認められ, 窒化時 間の増加にともなって $\delta$-TaN の生成が認められるよう になった. 10 分間の窒化によっては $\delta-\mathrm{TaN}$ と $\beta-\mathrm{Ta}_{2} \mathrm{~N}$ が認められ, $\delta$ - TaN の格子定数は $4.33 \sim 4.34 \AA$ であり, その組成は $\mathrm{TaN}_{0.85} \sim \mathrm{TaN}_{0.95}$ と見積もられる.

窒化したタンタルの低温における抵抗測定結果を, 抵 抗と温度の関係として図 1 に示す. 超伝導転移温度は約 $9 \mathrm{~K}$ であった．図1にはさきに $\varepsilon-\mathrm{TaN}$ のプラズマによ る加熱急冷によっで得られた粉末の自己インダクタンス 法による測定結果をあわせて示してある． $\varepsilon-\mathrm{TaN}$ の加 熱急冷によっては, $\varepsilon-\mathrm{TaN}, \beta-\mathrm{Ta}_{2} \mathrm{~N}$ および $\delta$ - TaN の混 合物が得られ， $\varepsilon-\mathrm{TaN}$ および $\beta-\mathrm{Ta}_{2} \mathrm{~N}$ は $4.2 \mathrm{~K}$ まで超伝 導性を示さなかったことからこの転移温度は $\delta$ - TaN によるとした．このことから本実験において得られた生 成物の示す超伝導転移温度も $\delta$ - TaN によるものと考え られる.

以上得られた結果より，本実験においては， $\delta$ - TaN$\varepsilon-\mathrm{TaN}$ の相転移温度 $\left(1700^{\circ} \mathrm{C}\right)$ より高温にタンタル表 面が加熱されていることから，この温度からの急冷に よって， $\delta$-TaN を室温において得ることが可能となる. 例えば，スプラット溶融法占によれば， $10^{6} \mathrm{Ks}^{-1}$ の急冷 速度によって高温安定相が室温においても得られてい る. 又, 粉末 $\varepsilon-\mathrm{TaN}$ のプラズマジェットによる加熱-急 冷の際には，10 $1 \mathrm{Ks}^{-1}$ の急冷速度が見積もられている。

本実験において窒化されたタンタルはプラズマジェッ

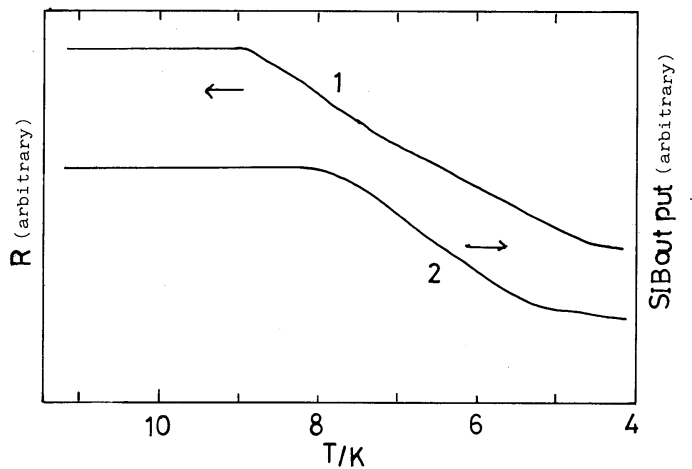

Fig. 1. Electrical resistance and self inductance bridge (SIB) out put vs. temperature of tantalum nitrides.

$1:$ Electrical resistance vs. temperature in nitrided tantalum,

$2:$ SIB out put vs. temperature in product obtained by heating of $\varepsilon$-TaN.

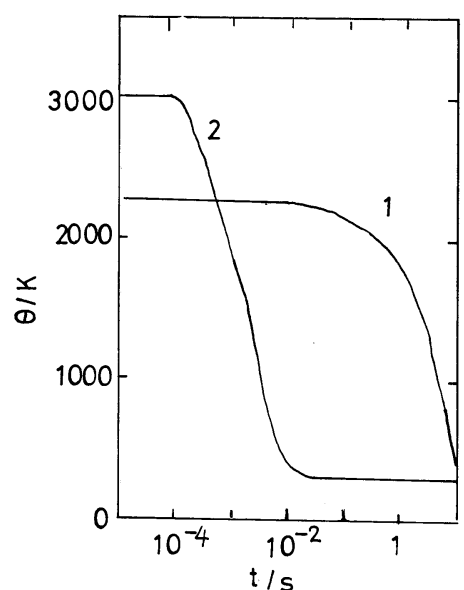

Fig. 2. $\theta$ vs. time of tantalum nitride in plasma jet heating.

1 : Nitriding of tantalum in the plasma jet,

2 : Heating of $\varepsilon$-TaN in the plasma jet.

トが遮断された直後に表面からの放熱によって放冷され ると仮定すると，熱伝導方程式は（1）式で与えられ $ろ^{6)}$.

$$
\frac{\partial \theta}{\partial t}=\alpha\left(\frac{\partial^{2} \theta}{\partial x^{2}}\right)
$$

ここで $\theta$ は熱伝導ポテンシャル， $t$ は時間， $\alpha$ は熱拡散 率， $x$ は距離である.（1）式は（2）式で示される境 界条件および初期条件によって解くことができる.

$$
\left.\begin{array}{l}
\left(\frac{\partial \theta}{\partial t}\right)_{x=l}=-\frac{h}{k} l,\left(\frac{\partial \theta}{\partial t}\right)_{x=-l}=\frac{h}{k} l \\
\theta_{t=0}=\theta_{0} \quad 0<x<0
\end{array}\right\}
$$

ここで $h$ は熱伝達係数， $k$ は熱伝導率である.

（1）式の解は，（3）式で与えられる.

$$
\frac{\theta}{\theta_{0}}=\phi\left(\frac{\alpha t}{l^{2}}, \frac{x}{l}\right)
$$

それぞれの数值を代入し，Bochmann 図を利用する ことによってタンタル表面温度 $\theta$ と時間 $t$ との関係を 求めることができる．得られた結果を図 2 に示す。冷却 速度は $10^{2} \sim 10^{3} \mathrm{Ks}^{-1}$ と見積もられ，図 2 中に一緒に示 した粉末の加熱急冷の際の冷却速度 ${ }^{7)}$ に比してかなり小 さい冷却速度で $\delta$-TaN が得られることが分かった。

\section{文献}

1) J. Getterer, G. Duffek, P. Ettmeyer and R. Kieffer, Monasch. Chem., 106, 1137-47 (1975).

2) L. G. Boiko and V. Popova, JETP Lett., 12, 70-71 (1970).

3) O. Matsumoto, M. Konuma and Y. Kanzaki, J. LessCommon Met., 60, 147-49 (1978).

4) O. Matsumoto, E. Hayami, M. Samejima and Y. Kanzaki, Plasma Chem. Plasma Process., 4, 33-42 (1984).

5) R. H. Willens and E. Buehler, Trans. Met. Soc. AIME, 236, 171-74 (1966).

6) H. Grober and S. Erk, "Fundamentals of Heat Transfer", McGraw Hill (1961) p. 43-61.

7) O. Matsumoto, M. Konuma and Y. Kanzaki, Plasma Chem. Plasma Process. , 1, 73-82 (1981). 